\title{
PENGARUH MODAL KERJA DAN MOTIVASI BERWIRAUSAHA TERHADAP KEMANDIRIAN USAHA PARA PETERNAK JANGKRIK DI KOTA DEPOK
}

\section{(THE EFFECT OF WORKING CAPITAL AND ENTREPRENEURSHIP MOTIVATION ON THE BUSINESS INDEPENDENCE OF CRICKET BREEDERS)}

\author{
Oleh: \\ Eka Giovana Asti ${ }^{1)}$, Widodo'), Titin Meidarti ${ }^{3)}$ \\ Sekolah Tinggi Ilmu Ekonomi IPWI Jakarta 1,23) \\ ekagiovanaasti@yahoo.co.id ${ }^{1)}$, widodomursanih@gmail.com ${ }^{2)}$, Titin2meidarti@gmail.com³)
}

Submit: 23 Dec 2019 Review: 10 Apr 2020 Accept: 26 Apr 2020 Publish: 30 Apr 2020

\begin{abstract}
This research was conducted in order to find out whether or not the influence of working capital and entrepreneurship motivation on the business independence of cricket breeders in the city of Depok. Where the independent variables namely working capital and entrepreneurship motivation affect business independence as the dependent variable. The population in this study were cricket breeders in the city of Depok. Samples were taken as many as 30 respondents. After conducting multiple regression tests, the results show a straight and positive relationship seen from the contribution of the variable Working Capital and Entrepreneurial Motivation to the Independence of Cricket Farmers in Depok, with an equation of: $Y=5.741+0.141 X 1+0.73 X 2$.
\end{abstract}

Keywords: Working Capital, Entrepreneurial Motivation and Business Independence

\section{ABSTRAK}

Penelitian ini dilakukan dalam rangka untuk mengetahui ada atau tidaknya pengaruh modal kerja dan motivasi berwirausaha terhadap kemandirian usaha para peternak jangkrik di Kota Depok. Dimana variabel independen yaitu modal kerja dan motivasi berwirausaha mempengaruhi kemandirian usaha sebagai variabel dependennya. Populasi dalam penelitian ini adalah para peternak jangkrik di kota Depok. Sampel diambil sebanyak 30 orang responden. Setelah melakukan uji regresi berganda, ditemukan hasil yang menunjukkan hubungan lurus dan positif dilihat dari kontribusi variabel Modal Kerja serta Motivasi Berwirausaha terhadap Kemandirian Usaha Peternak Jangkrik di Depok, yaitu dengan persamaan sebesar: $Y=5,741+0,141 X_{1}+0,73 X_{2}$.

Kata kunci: Modal Kerja, Motivasi Berwirausaha dan Kemandirian Usaha. 


\section{PENDAHULUAN}

Semakin banyak masyarakat memahami pentingnya dekat dengan alam, sehingga banyak masyarakat yang memilih hobi dengan bertaman, berkebun dan juga memelihara binatang. Masyarakat yang hobi memelihara binatang seperti ikan hias, burung, kucing dan lain sebagainya, merupakan peluang pasar bagi para peternak makanan binatang peliharaan tersebut. Salah satu diantaranya adalah jangkrik. Defoliart (1982) menyatakan, bahwa jangkrik sangat potensial untuk dibudidayakan sebagai bahan pangan dan pakan ternak karena memiliki palabilitas dan kandungan protein yang sangat tinggi, yaitu antara 58$62 \%$. Jangkrik dalam bentuk tepung dapat digunakan sebagai pakan burung berkicau, ikan arwana, pakan udang dan lele. Khusus untuk para penggemar hewan peliharaan burung yang berkicau indah, manfaat yang dapat diperoleh dari pakan tambahan yang berasal dari jangkrik adalah dapat meningkatkan mutu suara burung berkicau. Bagi penggemar hewan peliharaan ikan hias, khususnya ikan arwana, jangkrik dapat menambah kecemerlangan warna serta stamina pada ikan arwana.

Menurut kajian Siswoyo (2008) Permintaan akan jangkrik sebagai pakan ternak, sangat besar, hal inilah yang menjadikan usaha ternak jangkrik menjadi suatu peluang usaha yag menjanjikan bagi para calon pengusaha kecil.

Berdasarkan Penelitian dan Pengembangan (Litbang) Asosiasi Peternak Jangkrik Indonesia (ASTRIK) Pusat, yang pernah dilakukan, ditemukan sangat banyak sekali kandungan gizi pada jangkrik, diantaranya asam amino, asam lemak, kadar kolagen, omega 3 dan omega 6. Sehingga selain sebagai pakan ternak, jangkrik pun bisa dimanfaatkan untuk bahan baku industri farmasi, kosmetika, jamu.

Sudah merupakan kelumrahan didalam berwirausaha baik para pewirausaha pemula maupun yang telah berkecimpung didunia wirausaha, selalu saja akan menemui berbagai kendala. Hanya bedanya, untuk pewirausaha yang telah memiliki, mereka memiliki cara-cara tertentu guna mengatasi masalah dan kendala yang melanda usaha mereka, beda halnya dengan pewirausaha yang masih baru, jika masalah dan kendala yang mereka hadapi jika tidak dapat segera di atasi maka akan berdampak bagi kemajuan usahanya atau bahkan dapat membuat mereka menutup usahanya dalam watu yang sangat singkat.

\section{TUJUAN PENELITIAN}

Guna mencari tahu ada atau tidaknya pengaruh modal kerja dan motivasi berwirausaha terhadap kemandirian berwirausaha para peternak jangkrik di Kota Depok.

\section{TELAAH LITERATUR DAN PENGEMBANGAN HIPOTESIS Kemandirian Usaha}

Sukirman (2017) menemukan bahwa “jiwa kewirausahaan mempunyai pengaruh secara langsung terhadap perilaku kewirausahaan dan pengaruh tidak langsung terhadap kemandirian usaha". Menurut Qamariyah \& Dalimunthe (2012), "pengetahuan kewirausahaan, motif berprestasi, kemandirian pribadi mempunyai daya dukung terhadap kemandirian usaha."

Kemandirian berwirausaha adalah suatu sikap yang dimiliki seorang pribadi 
dimana kondisi dimana pribadi tersebut selalu lebih mengutamakan kemampuan diri sendiri,baik dalam bekerja, berkreatifitas juga berinovasi dalam kegiatan sehari-harinya untuk berusaha mencapai yang terbaik, akan tetapi pribadi tersebut pun akan tetap membuka diri untuk bekerja sama dengan orang lain guna mendapatkan kerjasama yang membawa manfaat bagi kedua belah pihak.

Kemandirian biasanya ditandai dengan memiliki kemampuan untuk menentukan nasib sendiri, berjiwa kreatif dan penuh inisiatif, dapat mengatur tingkah laku, bersikap penuh tanggung jawab, mampu menahan diri, mampu membuat keputusan-keputusan sendiri, serta mampu mengatasi masalah tanpa ada pengaruh dari orang lain. Sikap mandiri seorang usahawan bisa dibentuk dengan latihan dan belajar, dan diharapkan aka membentuk karakter yang mandiri. Karakteristik entrepreneur yang berhasil menurut Robinson, 1989 (Winardi, 2008: 37-40):
a) Memiliki Komitmen yang kuat,
b) Berusaha keras untuk mencapai prestasi,
c) Fokus ke tujuan,
d) Memiliki pengendalian internal,
e) Bisa menerima berbagai kemungkinan yang mungkin terjadi,
f) Tanggung menerima resiko,
g) Bersikap Adil
h) Memiliki kemampuan menyelesaikan masalah,
i) Terbuka mendapatkan feedback
j) Kuat menghadapi kegagalan.
Melalui Undang-undang tentang

Usaha Kecil (pasal 1 ayat 8 Permen KUKM No: $\quad$ 02/Per/M.KUKM/I/2008),

Pemerintah memberikan dukungan dan bimbingan guna menumbuhkan dan meningkatkan kemampuan Usaha Kecil agar dapat berkembang menjadi usaha yang tangguh dan mandiri.

\section{Modal Kerja}

Modal kerja adalah jumlah semua harta lancar yang dimiliki perusahaan, atau dapat pula dimaksudkan sebagai dana yang harus tersedia untuk membiayai kegiatan operasi perusahaan dalam melakukan kegiatan operasionalnya. Menurut Weston dan Brigham (1997: 239): "Modal kerja adalah investasi perusahaan di dalam aktiva jangka pendek seperti kas, sekuritas (surat-surat berharga), piutang dagang, dan persediaan." Manajemen modal kerja pada intinya adalah bagaimana mengatur pengadaan dan pembelanjaan harta lancar. Sasarannya adalah:

1. Memaksimalkan nilai perusahaan

2. Meminimalkan biaya modal jagka panjang.

3. Mengawasi arus dana harta lancar.

Semua jenis usaha baik tingkat perusahaan multinasional maupun tingkat wirausaha mutlak memerlukan modal kerja, untuk membiayai kegiatan operasional sehari-hari dan juga membayar kewajiban jangka pendek yang segera jatuh tempo. Secara umum modal kerja merupakan dana yang dibutuhkan untuk membiayai kegiatan operasional perusahaan yang meliputi kebutuhan kas, piutang usaha, persediaan, serta sejumlah kas minimum dibutuhkan untuk membiayai kebutuhan jangka pendekdan rutin perusahaan (Zubir, 2005)

Biaya investasi yang dikeluarkan pada usaha budidaya ternak jangkrik dengan skala pemeliharaan telur jangkrik sebanyak 1.200 gram meliputi pembangunan kandang, eggtray, sapu kecil dan sapu lidi. Biaya operasional dapat dibedakan menjadi dua, yaitu biaya tetap dan biaya variabel. Besarnya biaya operasional usaha budidaya ternak 
jangkrik terdiri atas Biaya tetap yaitu biaya penyusutan kandang, penyusutan peralatan, penyusutan eggtraydan listrik dan Biaya variabel terdiri atas upah penggilingan pakan penguat, pembelian telur jangkrik, pakan penguat (Konsentrat), tenaga kerja, pakan tambahan.

Besarnya biaya operasional usaha budidaya ternak bervariasi tergantung jumlah telur yang akan di tetaskan. Biaya tetap (Fixed Cost) adalah biaya yang sudah seharusnya disediakan untuk dikeluarkan secara rutin yang jumlahnya tidak dipengaruhi oleh jumlah jangkrik yang dipelihara. Sedangkan Biaya variabel (Variabel merupakan biaya yang dikeluarkan secara rutin dan dipengaruhi oleh jumlah jangkrik yang dipelihara . Adapun yang termasuk kedalam biaya variabel terdiri atas upah penggilingan pakan penguat $50 \mathrm{~kg}$,pembelian telur jangkrik, pakan penguat (Konsentrat), tenaga kerja, pakan tambahan dan eggtray Biaya tetap terdiri atas biaya penyusutan kandang, penyusutan peralatan, penyusutan eggtray dan listrik (Novendra et al. 2016).

\section{Motivasi Berwirausaha}

Motivasi merupakan dorongan dan kekuatan dalam diri seseorang untuk melakukan tujuan tertentu yang ingin dicapai. Pernyataan di atas dapat diartikan bahwa yang dimaksud tujuan adalah sesuatu yang berada di luar diri manusia. Dengan adanya tujuan, maka kegiatan manusia akan lebih terarah. Dengan adanya kegiatan untuk mencapai tujuan maka seesorang akan berusaha lebih semangat dan giat berbuat sesuatu

Menurut Robbins (2003: 207), "The willingness to exert high levels of effort toward organizational goals, conditioned by the effort's ability to satisfy some individual need". Bahwa motivasi adalah keikhlasan guna melakukan suatu usaha dengan kesungguhan hati untuk mencapai tujuan organisasi dengan upaya dalam memenuhi kebutuhan individual. Motivasi mempunyai beberapa unsur atau aspek, yaitu :

1) Adanya keinginan untuk melakukan sesuatu,

2) Adanya kebutuhan yang mendorong melakukan kegiatan,

3) Adanya pengharapan,

4) Penghormatan dan penghargaan atas diri pribdi,

5) Adanya lingkungan yang kondusif,

6) Adanya kegiatan yang mendukung. Motivasi juga merupakan salah satu faktor penentu hasil kerja seseorang disamping kemampuannya. sedangkan sesuatu yang menimbulkan semangat atau dorongan kerja disebut motivasi kerja. Motivasi yang akan disoroti dalam penelitian ini adalah motivasi berwirausaha yang merupakan salah satu variabel yang akan diduga dapat mempengaruhi peningkatan Kemandirian berwirausaha. Penelitian sebelumnya (Asti, 2018) kesimpulan bahwa Mental Wirausaha dan Kreatifitas memiliki pengaruh yang kuat bagi peningkatan Motivasi Berwirausaha, berkenaan dengan hal tersebut, penulis berkeinginan untuk meneliti lebih lanjut, apakah Motivasi Berwirausaha yang baik pada gilirannya juga akan dapat meningkatkan Kemandirian berwirausaha bagi para pewirausaha.

Menurut Longenecker (2001: 4) wirausaha merupakan pembuat keputusan yang membantu terbentuknya sistem ekonomi perusahaan yang bebas. Wirausaha juga merupakan seseorang yang memulai dan atau mengoperasikan bisnis. Jadi pada hakekatnya Wirausaha adalah suatu kemampuan untuk dapat menjadikan suatu kondisi dan objek untu dijadikan peluang bisnis. 
Menurut Nitisusastro (2012: 26) "wirausaha merupakan seseorang yang mengorganisasikan, mengoperasikan dan memperhitungkan risiko untuk sebuah usaha yang mendatangkan laba." Laba merupakan daya tarik yang sangat kuat bagi seseorang untuk melalukan wirausaha, akan tetapi ketertarikan laba saja tidak dapat secara langsung menggerakkan seseorang, perlu juga didorong oleh fikiran terdalam orang tersebut. Ketika manusia akan melakukan suatu kegiatan akan dipengaruhi oleh suatu kondisi psikologis yang mendorongnya untuk melakukan kegiatan tersebut. Kondisi psikologis tersebut berasal dari dalam tubuh manusia dan memberikan dampak yang cukup besar terhadap keberhasilan dari suatu kegiatan. Kondisi psikologis atau dorongan tersebut dinamakan motivasi.

Menurut Suryana \& Bayu (2010: 98) "motivasi berhubungan dengan dorongan atau kekuatan yang berada dalam diri manusia." Motivasi berada dalam diri manusia yang tidak terlihat dari luar. Sedangkan menurut Gerungan dalam Suryana \& Bayu (2010: 99) "motivasi merupakan dorongan dalam diri manusia yang menyebabkan manusia tersebut melakukan sesuatu."

Motivasi berwirausaha bukanlah kemampuan terpasang sejak awal, tetapi motivasi berwirausaha dapat dilatih, dipelajari dan dikembangkan. Motivasi berwirausaha merupakan suatu dorongan yang timbul dari diri seseorang untuk mengambil atau melakukan kegiatan yang berkaitan dengan bidang kewirausahaan.

Menurut Suryana \& Bayu (2010: 102117) motivasi memiliki tujuan untuk dapat menunjang karakteristik dari seorang wirausaha antara lain:

1) Giat Bekerja

Giat bekerja merupakan modal dasar untuk keberhasilan seseorang (wirausahawan). Kerja keras atau etos kerja keras sering dianggap sebagai mimpi kuno dan seharusnya diganti, tetapi hardwork and smartwork tidak dapat dipisahkan lagi. Jadi selain kerja keras, efektif dalam bekerja merupakan 2 hal yang tidak dapat dipisahkan.

2) Tidak Pernah Menyerah

Dalam menjadi seorang wirausaha, tidak diperkenankan memiliki sifat yang mudah menyerah. Banyak wirausahawan yang telah berhasil dan sukses setelah wirausahawan tersebut melewati tantangan dan tetap berjuang untuk meraih kesukesan.

3) Memiliki Semangat

Seorang wirausahawan harus selalu gembira di dalam setiap situasi. Kegembiraan tersebut yang menjadi semangat untuk menjadi kekuatan. Dengan semangat dan kekuatan akan menumbuhkan keberanian yang akan mendukung keberhasilan.

4) Memiliki Komitmen

Komitmen merupakan proses pada individu untuk menyesuaikan denga aturan, nilai dan tujuan dari perusahaan. Seorang wirausaha yang baik akan memiliki komitmen yang kuat untuk memberikan tenaga dan tanggung jawab yang dapat memajukan bisnisnya.

Faktor-faktor yang akan mendorong sseorang melakukan wirausaha Menurut Saiman (2009: 26) mengemukakan empat faktor motivasi seseorang untuk berwirausaha, yaitu sebagai berikut:

1) Laba

Merupakan kekuatan yang dapat membuat seseorang melakukan suatu kegiatan usaha

2) Kebebasan

Bebas mengapresiasiasikan diri dan bekerja dan berbudaya kerja. 
3) Impian Personal

Bebas menentukan impian dan harapan.

4) Kemandirian

Mandiri dalam bertindak dan menentukan target yang akan dicapai

\section{Pengembangan Hipotesis}

Penelitian sebelumnya oleh Sugiyono (2015) mendapatkan penemuan bahwa dengan penyediaan modal kerja yang cukup akan meningkatkan laba usaha. Selain itu penelitian oleh Sukirman (2017) menemukan bahwa pada kelompok usaha kecil masih mengalami kesulitan dalam mengelola organisasi, pemasaran, strategi usaha dan pengelolaan tenaga kerja.

Merujuk dari kedua penelitian ini, terlihat fenomena bahwa guna mendapatkan kondisi agar usaha kecil dapat kemandirian usaha mencermati modal kerja juga pengelolaan sumber daya manusia nya, sehingga penulis akan menyoroti dari segi motivasi berwirausahanya. Jadi bentuk Model hubungan antara variabel bebas dengan variabel terikat dalam penelitian ini bisa dilihat pada gambar berikut:

Gambar 1

Kerangka Penelitian

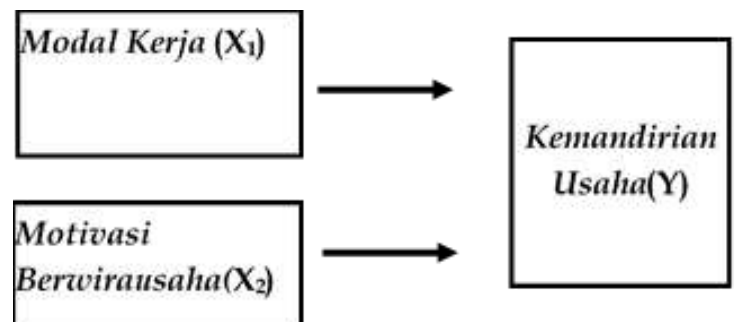

\section{METODE PENELITIAN}

\section{Sampel Penelitian}

Dalam penelitian ini yang menjadi populasi atau responden penelitian adalah para Peternak Jangkrik di Kota Depok, yaitu sebanyak 30 orang. Dikarenakan terbatas nya jumlah peternak jangkrik yang dapat dijumpai di Kota Depok, sehingga jumlah populasi adalah kurang dari 100, maka seluruh populasi dijadikan sebagai sampel penelitian.

\section{Desain Penelitian}

Jenis penelitian yang digunakan dalam penelitian ini adalah metode explanatory research tipe kausal yang akan menguji pengaruh variabel bebas yaitu Modal Kerja dan Motivasi Berwirausaha terhadap variabel terikat yaitu Kemandirian Usaha.

\section{Operasionalisasi Variabel}

Operasionalisasi variabel penelitian dapat dituangkan dalam bentuk table sebagai berikut:

Tabel 1

Operasionalisasi Variabel

\begin{tabular}{|c|c|c|c|}
\hline Variabel/ Konsep & & Indikator & Skala \\
\hline $\begin{array}{l}\text { Modal Kerja ( } \mathrm{X}_{1} \text { ) adalah investasi } \\
\text { perusahaan di dalam aktiva jangka } \\
\text { pendek (Weston dan. Brigham, } \\
\text { 1997: 239) }\end{array}$ & $\begin{array}{l}\text { b) } \\
\text { c) }\end{array}$ & $\begin{array}{l}\text { Piutang } \\
\text { usaha, } \\
\text { Persediaan, } \\
\text { Kas }\end{array}$ & $1-5$ \\
\hline $\begin{array}{l}\text { Motivasi Berwirausaha }\left(\mathrm{X}_{2}\right) \text { adalah } \\
\text { dorongan yang timbul dari diri } \\
\text { seseorang untuk mengambil atau } \\
\text { melakukan kegiatan yang berkaitan } \\
\text { dengan bidang kewirausahaan. } \\
\text { (5uryana \& Bayu, 2010:99) }\end{array}$ & $\begin{array}{l}\text { a) } \\
\text { b) } \\
\text { c) }\end{array}$ & $\begin{array}{l}\text { Laba } \\
\text { Kebebasan } \\
\text { Impian } \\
\text { Personal } \\
\text { Kemandirian }\end{array}$ & $1-5$ \\
\hline $\begin{array}{l}\text { Kemandirian Usaha (Y) adalah } \\
\text { kemampuan untuk menentukan } \\
\text { nasib sendiri, berjiwa kreatif dan } \\
\text { penuh inisiatif, dapat mengatur } \\
\text { tingkah laku, bersikap penuh } \\
\text { tanggung jawab, mampu menahan } \\
\text { diri, mampu membuat keputusan- } \\
\text { keputusan sendiri, serta mampu } \\
\text { mengatasi masalah tanpa ada } \\
\text { pengaruh dari orang lain. } \\
\text { (Desmita, 2010: 185) }\end{array}$ & d) & $\begin{array}{l}\text { Memenuhi } \\
\text { sendiri } \\
\text { Tidak mudah } \\
\text { menyerah } \\
\text { Berani ambit } \\
\text { keputusan } \\
\text { Berani } \\
\text { bersaing } \\
\text { Menerima } \\
\text { keunggulan } \\
\text { pesaing }\end{array}$ & $1-5$ \\
\hline
\end{tabular}

\section{Metode Analisis}

\section{Uji Validitas dan Realibilitas}

Guna mengetahui validitas dan reliabilitas kuisioner perlu dilakukan pengujian atas kuisioner dengan menggunakan uji validitas dan uji reliabilitas. 


\section{Uji Asumsi Klasik}

Uji Asumsi Klasik yang akan digunakan adalah: Uji linearitas, Uji normalitas, Uji multikolonearitas, Uji Heteroskedastisitas dan Uji Autokorelasi.

\section{Koefisien Korelasi dan Determinasi}

Koefisien korelasi dan determinasi menunjukkan kemampuan model hasil analisis (persamaan regresi) dalam menjelaskan pengaruh variable independen terhadap variable dependen. Disini dapat diartikan pula sebagai tingkat kemampuan variable independen dalam menjelaskan variasi variable dependen.

\section{Model Regresi Berganda}

Persamaan analisa regresi berganda akan (dua prediktor) yang akan dicari adalah sebagai berikut: $\mathrm{Y}=\mathrm{a}+\mathrm{b} 1 \mathrm{X} 1+$ b2X2.

\section{Uji Hipotesis}

Guna menguji kebenaran suatu hipotesis, dan menentukan keputusan mana yang akan diterima maka perlu dilakukan Uji hipotesis, yang merupakan suatu prosedur untuk pembuktian kebenaran sifat populasi berdasarkan data sampel.

\section{HASIL PENELITIAN DAN \\ PEMBAHASAN}

Hasil Penelitian

\section{Uji Validitas dan Reliabilitas}

Setelah dilakukan pengujian uji validitas terhadap 30 item pertanyaan tersebut di atas, ternyata semua instrumen penelitian menunjukkan angka lebih besar dari $r$ tabel. Hal ini menunjukkan bahwa alat ukur yang digunakan telah valid dan dapat digunakan sebagai indikator dalam penelitian ini.

Hasil uji reliabilitas menunjukkan bahwa alat ukur yang digunakan didalam penelitian ini $100 \%$ reliabel $(\alpha>0,6)$ yaitu variabel $X_{1}$ ( Modal Kerja) sebesar 0,694, variabel $\mathrm{X}_{2}$ (Motivasi Berwirausaha) sebesar 0,795 , dan variabel Y (Kemandirian Usaha) sebesar 0,743. Hal ini menunjukkan bahwa semua variabel bebas dan variabel terikat dapat dinyatakan reliabel.

\section{Uji Asumsi Klasik}

Berdasarkan Hasil Uji Linieritas Ditemukan hubungan masing-masing variabel bebas terhadap variabel terikat adalah linier, begitu puka Hasil Uji Normalitas dengan menggunakan tes Kolomogorov-Smirnov (KS) pun ternyata tidak ditemukan variabel pengganggu atau residual dalam model regresi, selanjutnya berdasarkan hasil Pengujian multikolonearitas tidak ditemukan adanya korelasi diantara variabel bebas, sedangkan hasil Uji heteroskedastisitas dalam penelitian ini dengan cara uji Gjejser menunjukkan nilai Sig. ternyata semua variabel adalah $>0,05$, artinya tidak ada indikasi heteroskedastisitas, dan Uji autokorelasi mendapat hasil bahwa tidak terdapat korelasi antara kesalahan pengganggu pada periode $t$ dengan kesalahan pada periode t-1 (sebelumnya).

\section{Koefisien Korelasi dan Determinasi}

Hasil analisis regresi sebagai disajikan pada table berikut:

\section{Tabel 2}

Model Summary

Model Summaryb

\begin{tabular}{|r|r|r|r|r|r|}
\hline Model & $\mathrm{R}$ & $\begin{array}{c}\mathrm{R} \\
\text { Square }\end{array}$ & $\begin{array}{r}\text { Adjusted } \\
\text { R Square }\end{array}$ & $\begin{array}{c}\text { Std. } \\
\text { Error of } \\
\text { the } \\
\text { Estimate }\end{array}$ & $\begin{array}{l}\text { Durbin- } \\
\text { Watson }\end{array}$ \\
\hline 1 & $.746^{\mathrm{a}}$ & 0.556 & 0.523 & 2.321 & 1.978 \\
\hline
\end{tabular}

a. Predictors: (Constant), Motivasi Berwirausaha, Modal Kerja

b. Dependent Variable: Kemandirian Usaha

Berdasarkan tabel di atas ditemukan bahwa Koefisien Determinasi antara Motivasi Berwira Usaha dan Modal Kerja 
terhadap Kemandirian Usaha Peternak Jangkrik di Kota Depok adalah sebesar 0,556 , yang artinya naik turunnya nilai kemandirian usaha para perternak jangkrik di Kota Depok yang disebabkan oleh modal kerja dan motivasi berwirausaha adalah sebesar 55,6 persen dan sisanya 44,4 persen disebabkan faktorfaktor lainnya

\section{Model Regresi Berganda}

Hasil pengujian Analisa regresi linier berganda adalah digunakan untuk mengetahui pengaruh variabel bebas $\left(X_{1}\right)$ dan $\left(X_{2}\right)$ terhadap variabel terikat $(Y)$. Adapun persamaan regresi yang digunakan dalam penelitian ini adalah: $Y=$ $a+b_{1} X_{1}+b_{2} X_{2}$.

Hasil perhitungan regresi linier berganda dengan bantuan program SPSS adalah sebagai berikut:

Tabel 3

Tabel Koefisien

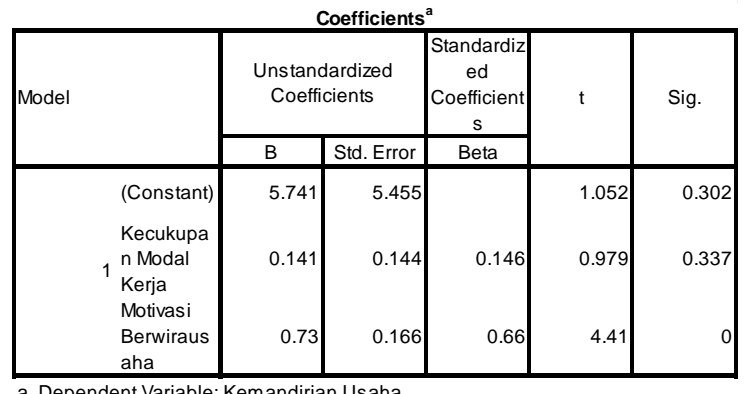

a. Dependent Variable: Kemandirian Usaha

Sumber : Data diolah.

Berdasarkan hasil analisa regresi di atas, maka dapat disusun persamaan regresi, yaitu: $Y=5,741+0,141 X_{1}+0,73 X_{2}$. Kemudian interpretasi dari persamaan tersebut adalah sebagai berikut:

a. Konstanta $(a=5,741)$, artinya angka ini menunjukkan kualitas Kemandirian Usaha tetap ada, meskipun modal kerja dan motivasi berwirausaha relative tidak ada.

b. Koefisien regresi $\left(b_{1}=0,141\right)$, artinya jika Modal Kerja bertambah maka kualitas Kemandirian Usaha Peternak
Jangkrik di Kota Depok akan bertambah.

c. Koefisien regresi $\left(b_{2}=0,73\right)$, artinya jika Motivasi Berwirausaha bertambah maka Kemandirian Usaha Peternak Jangkrik di Kota Depok akan bertambah.

\section{Uji Hipotesis}

a. Hipotesis 1 (H1) Pengaruh Modal Kerja terhadap Kemandirian Usaha Berdasarkan tabel output SPSS di atas diketahui nilai signifikansi (Sig) variabel modal kerja (X1) adalah sebesar 0,337. Karena nilai Sig. 0,337 > probabilitas 0,05, maka dapat disimpulkan bahwa $\mathrm{H} 1$ atau hipotesis pertama ditolak. Artinya tidak ada pegaruh yang signifikan antara modal kerja (X1) terhadap kemandirian usaha.

b. Hipotesis $2(\mathrm{H} 2)$ Pengaruh Motivasi Berwirausaha terhadap Kemandirian Usaha

Berdasarkan tabel output SPSS di atas diketahui nilai signifikansi (Sig) variabel mptivasi berwirausaha (X2) adalah sebesar 0,00 . Karena nilai Sig. $0,00<$ probabilitas 0,05 , maka dapat disimpulkan bahwa $\mathrm{H} 2$ atau hipotesis kedua diterima. Artinya ada pegaruh yang signifikan antara motivasi berwirausaha (X2) terhadap kemandirian usaha.

\section{Pembahasan}

Pengaruh Modal Kerja terhadap Kemandirian Usaha

Modal kerja bukanlah hal yang mutlak akan dapat meningkatkan kemadirian usaha, walaupun Secara umum modal kerja merupakan dana yang seyogyanya harus ada dalam bentuk harta lancar (Zubir, 2005).

Penelitian serupa telah dilakukan oleh Oleh Muhammad Nur Hidayatullah, 
dengan penelitian berjudul " Pengaruh Modal dan Tenaga Kerja Usaha Pengrajin Batik Tulis Klasik Terhadap Tingkat Produksi" , hasil penelitian menemukan bahwa variabel yang dominan bagi peningkatan produksi adalah Tenaga Kerja, bukan Modal.

\section{Pengaruh Motivasi Berwirausaha terhadap Kemandirian Usaha}

Kemandirian usaha yang akan dijadikan variabel terikat dalam penelitian ini adalah kemandirian usaha khususnya bagi pengusaha mikro yaitu para peternak jagkrik khususnya di kota Depok. kemandirian adalah suatu kondisi dimana seseorang dapat berdiri sendiri, dapat mencari, membuat, mengurus atau mengatasi kepentingannya sendiri tanpa bantuan orang lain.

Dalam penelitian ini ditemukan bahwa guna mendukung kemandirian usaha menjadi lebih baik adalah dengan lebih meningkatkan Motivasi Berwira Usaha, karena dengan memiliki Motivasi berwirausaha yang tinggi akan membuat seorang pribadi, khususnya pengusaha akan memiliki tenaga dalam diri yang sangat kuat untuk mendorongnya melakukan pekerjaannya, pantang menyerah, semangat tinggi dan memiliki komitmen yang tinggi.

\section{KESIMPULAN}

a. Variabel Modal Kerja tidak signifikan berpengaruh terhadap Kemandirian Usaha.

b. Motivasi Berwirausaha berpengaruh positif terhadap Kemandirian Usaha, artinya bahwa seseorang yang memiliki Motivasi Berwirausaha yang tinggi, seseorang tersebut pun akan dapat berusaha mandiri Khususnya dalam penelitian ini adalah peternak jangkrik di Kota Depok

\section{SARAN}

a. Dalam rangka meningkatkan kemandirian usaha kecil, khususnya para peternak jangkrik di kota Depok, sanga perlu diberi pengetahuan dan inspirasi akan motivasi dalam berwirausaha, dengan pemdampingan, memberikan pelatihan, berkunjung ke peternak yang sudah lebih dahulu eksis di usaha peternakan jangkrik, juga sangat baik jika dan membuat kelompok usaha sejenis dan koperasi sehingga dapat lebih memberi manfaat dari berbagai peluang dan pengetahuan yang lebih maju.

b. Karena berdasarkan hasil penelitian, Modal Kerja tidak signifikan mempengaruhi peningkatan Kemandirian Usaha, maka sangat penting diberika pengetahuan kepada para peternak jangkrik, bahwa yang dapat lebih memicu lebih berkembangnya kemajuan dari usaha ternak jangkrik adalah kerja keras, komitmen dan rajin mencari peluang pemasaran, dibandingkan dengan terlalu terfokus kepada jumlah Modal Usaha.

\section{DAFTAR PUSTAKA}

Asti, Eka Giovana, 2018, "Analisis Pengaruh Mental Wirausaha Dan Kreativitas Terhadap Motivasi Berwirausaha Pada Pengusaha Rumah Makan Di Kelurahan Padurenan, Bekasi", Jurnal Pengembangan Wiraswasta Vol 20 No. 03, STIE IPWI Jakarta

Muhammad Nur Hidayatullah, 2013. Pengaruh Modal dan Tenaga Kerja Usaha Pengrajin Batik Tulis Klasik Terhadap Tingkat Produksi, Jurnal Ekonomi Pembangunan, Univesitas Muhamadiyah Malang

Longenecker, 2001, Kewirausahaan Manajemen Usaha kecil, Jakarta 
Novendra et al, 2016, Peternakan Tropika Vol. 4 No. 2. Universitas Udayana, Bali

Nitisusastro, Mulyadi, 2012, Kewirausahaan dan Manajemen Usaha Kecil, Jakarta

Qamariyah, I, dan D. M. J. Dalimunthe. 2012. "Pengaruh pengetahuan kewirausahaan, motif berprestasi, dan kemandirian pribadi terhadap daya saing usaha (pengusaha kuliner skala kecil di jalan Dr. Mansur Medan)." Jurnal Ekonomi

Robbins, Stephen P, 2003, Organization Behavior, 9th Edition (Perilaku Organisasi, Edisi ke-9), Edisi Indonesia, Indeks, Kelompok Gramedia, Jakarta

Saiman, L, 2009, Kewirausahaan, Teori, Praktik, dan Kasus-kasus, Salemba Empat, Jakarta

Siswoyo, 2008, "Pengembangan Usaha Budidaya Jangkrik Sebagai Bahan Baku Industri" (Studi Kasus Di Daerah Istimewa Yogyakarta) Jurnal MPI Vol. 3 No. 2.

Sugiyono. 2015, Prosiding Seminar Nasional Pendidikan Ekonomi \& Bisnis, Fakultas
Keguruan dan Ilmu Pendidikan Universitas Sebelas Maret Surakarta,.

Sugiyono, 2015, "Analisis Penyediaan Dan Penggunaan Modal Kerja UMKM (Usaha Mikro, Kecil Dan Menengah)" Fakultas Keguruan dan IImu Pendidikan Universitas Sebelas Maret, Surakarta

Sukirman, 2017 "Jiwa Kewirausahaan Dan Nilai Kewirausahaan Meningkatkan Kemandirian Usaha Melalui Perilaku Kewirausahaan", Jurnal Ekonomi dan Bisnis, Volume 20 No 1.

Suryana, Yuyus dan Bayu Kartib, 2001, Kewirausahaan: Pendekatan Karakteristik Wirausahawan Sukses, Kencana Prenada Media Group, Jakarta

Weston J. Fred dan Eugene F. Brigham, 1997. Manajemen Keuangan Jilid 2, Bina Rupa Aksara 